\title{
Успішне лікування пацієнта з ножовим наскрізним пораненням аорти та нижньої порожнистої вени через дві доби з моменту травми
}

\author{
Ю. А. Левчак \\ Закарпатська обласна клінічна лікарня імені А. Новака, м.Ужгород

\section{Successful treatment of a patient, suffering the knife perforating wounding of aorta and vena cava inferior in two days from a trauma moment}

\author{
Yu. A. Levchak \\ Zakarpattya Regional Clinical Hospital named after A. Novak, Uzhgorod
}

Поєднані травматичні пошкодження аорти та нижньої порожнистої вени (НПВ) відносять до числа найбільш серйозних та складних травм з хірургічної точки зору, оскільки смертність внаслідок таких пошкоджень наближається до 100\% [1].

Характерними особливостями проникаючих поранень живота з пошкодженням магістральних судин є, як правило, молодий вік постраждалих (у середньому 31,6 року), а також висока смертність на етапі транспортування до лікувального закладу (за даними різних авторів - від 83,4 до 92,5\% [2, 3]). Складність ситуації зумовлена ще й тим, що таких пацієнтів госпіталізують до загально-хірургічних стаціонарів, де допомогу надають загальні хірурги, які мають недостатній рівень підготовки у плані судинної хірургії, що призводить до низки тактичних і технічних помилок і, як наслідок, високої (53 - 85\%) післяопераційної смертності [4].

Метою даної публікації $€$ висвітлення основних лікувально-діагностичних проблем, які виникають під час надання хірургічної допомоги постраждалим із проникаючими пораненнями живота у поєднанні з пошкодженням магістральних судин. Наводимо спостреження.

Паціент Л., 28 років, отримав ножове поранення живота 06.08.2000 р. о 1 год 15 хв у ході спецоперації (офіцер загону спеціального призначення однієї з силових структур). Бригадою швидкої допомоги доставлений у міську лікарню протягом 25 хв. Оглянутий лікарем приймального відділення о 1 год 40 хв та черговим хірургом о 1 год 45 хв (історія хвороби №11237). Встановлено діагноз: ножове поранення живота. Під час огляду: хворий збуджений, шкірні покрови різко бліді, артеріальний тиск 10,7/6,7 кПа (80/50 мм рт. ст.), пульс ниткоподібний. Аналіз крові під час госпіталізації (1 год 40 хв): гемоглобін 138 г/л, ер. 3,18 × 10 12 в 1 л, л. 10,0 × 109 в 1 л. Операційне втручання розпочато тільки через 8 (!) год з моменту госпіталізації. Під час операції (протокол №141/29) виявлено дві рани в тонкій кишці на відстані 60 см від зв'язки Трейтца (одна наскрізна - розмірами 0,5 × 1,0 см та одна дотична - розмірами 0,3 × 1,0 cм), рани брижі тонкої кишки, пошкодження парієтальної очеревини розмірами 0,5 × 1,0 см та позаочеревинна гематома великих розмірів. Рани в тонкій кишці та іiі брижі послідовно зашиті, ревізії позаочеревинного простору не виконували (!). Післяопераційний період супроводжувався гіпотонією - 12,0/8,0 кПа (90/60 мм рт. ст.) та анемією тяжкого ступеня (гемоглобін 42,5 г/л, ер. 1,2 × 1012 в 1 л). Хворому проводили постійні замісні гемотрансфузії.

08.08.2000 (більше ніж через 2 доби з моменту травми) хворий консультований судинним хірургом та одразу переведений в операційну для повторного операційного втручання. В проекції біфуркації аорти - масивна позаочеревинна гематома (2 л). Після евакуації згортків виникла потужна артеріальна кровотеча - виявлена рана розмірами 0,5 × 1,0 см над біфуркацією аорти, яка зашита безперервно (4/0, поліпропілен). Під час подальшої ревізії виявили пошкодження задньої стінки аорти з переходом на гирло загальної клубової артерії (ЗКА) та НПВ. Для повної візуалізації пошкодження НПВ ЗКА пересічена в зоні пошкодження задньої стінки. Виявлена рана в НПВ розмірами 0,5 × 1,0 см, яка зашита безперервно. При пораненнях НПВ доцільно використовувати шовний матеріал із політетрафторетилену (ПТФЕ), оскільки у порівнянні з поліпропіленом нитка з ПТФЕ менш схильна до прорізування стінки вени. Виконали резекцію пораненого початкового відділу ЗКА діастаз 2,5 см. Здійснили протезування сегмента ЗКА лінійним протезом із ПТФЕ діаметром 6 мм (протеза необхідного діаметра не було). Проведено ревізію правого сечовода - пошкоджень не виявлено.

Ранній післяопераційний період ускладнився гострим ураженням нирок (калій 5,5 ммоль/л, сечовина 33,3 ммоль/л, креатинін 1088,0 мкмоль/л). Хворому проведені три гемодіалізи. Функція нирок відновлена. Діагностовано порушення 


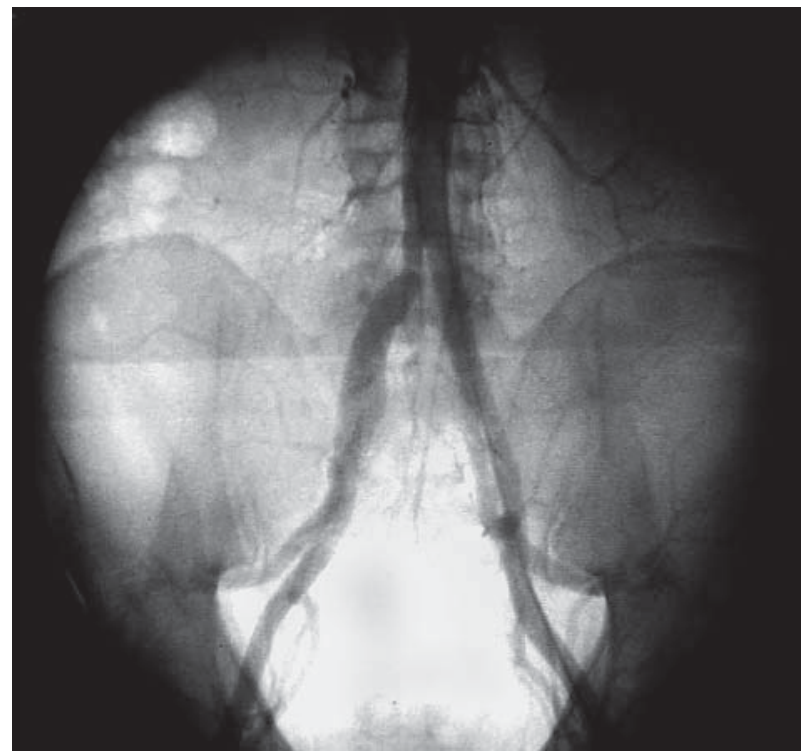

місце протезування ЗКА (діаметр протеза б мм).

спінального кровообігу за ішемічним типом з нижнім парапарезом. Проведено відповідне лікування та реабілітацію (хворий заново вчився ходити). Через 5 міс пацієнт повернувся на попереднє місце служби. Оглянутий через 10 років: скарг немає, пульс на всіх сегментах чіткий, місце служби попереднє. Виконали аортографію: зона реконструкції прохідна (див. рисунок). У 2017 р. повторний огляд судин- ного хірурга: скарг немає. Ультразвукове дуплексне сканування: лінійні та об'ємні швидкості кровотоку по гомілкових артеріях у межах норми. У 2017 р. за вислугою років вийшов на пенсію.

У контексті обговорення слід зауважити, що у разі найменшої підозри на пошкодження магістральних судин необхідно терміново залучати вузьких спеціалістів. Окрім цього, дане спостереження демонструє проблему забезпечення ургентних підрозділів розхідними матеріалами, зокрема, штучними судинами. Замість надання негайної спеціалізованої допомоги хворому судинний хірург змушений був опікуватися забезпеченням операційного втручання.

Таким чином, проникаючі ножові поранення черевної порожнини з пошкодженням магістральних судин є вкрай загрозливими для життя постраждалих, потребують термінової полівалентної хірургічної допомоги та відповідного забезпечення.

\section{References}

1. Marcos B, Perez Y, Matarlo J, Yelon JA, Katz V, Madlinger RV. Combined aortic and inferior vena. IJCRI. 2013;4(1):51-4.

2. Kosmin YeA, Vaganova TN, Kuznecov AI, Iametdinov AA. Uspeshnoe lechenie nozhevogo ranenija brjushnoj aorty. Vestnik hirurgii im. I. I. Grekova. 1998;(1):84. [In Russian].

3. Navsaria PH, de Bruyn P, Nicol AJ. Penetrating abdominal vena cava injuries. EJVES. 2005 Nov;30(5):499-503.

4. Baeshko AA, Klimovich VV, Voevoda MT, Orlovsky YeN, Gornostai PV, Yuskevich VA. Ranenie nizhnej poloj veny. Hirurgija. Zhurnal im. N.I. Pirogova. 2006;(4):12-9. [In Russian]. 